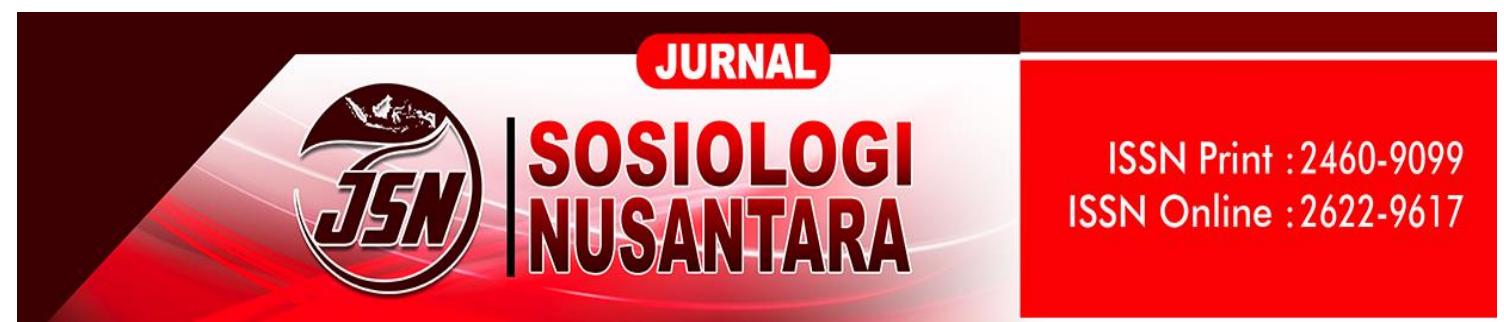

https://ejournal.unib.ac.id/index.php/jsn

DOI ://doi.org/10.33369/jsn.7.2.311-330

\title{
KEPUASAN MAHASISWA TERHADAP LAYANAN PENDIDIKAN JURUSAN SOSIOLOGI
}

\section{STUDENT SATISFACTION WITH EDUCATIONAL SERVICES SOCIOLOGY DEPARTMENT}

\author{
Diyas Widiyarti ${ }^{1}$, Heni Nopianti ${ }^{2}$, Ika Pasca Himawati ${ }^{3}$ \\ diyas.widiyarti@unib.ac.id,nopiantiheni@gmail.com,mengdawati2003@gmail.com
}

1,2.3 Universitas Bengkulu

\begin{abstract}
ABSTRAK
Fokus penelitian ini adalah pengkajian mengenai kepuasan mahasiswa terhadap layanan pendidikan dan kemahasiswaan Jurusan Sosiologi. Penelitian ditujukan kepada mahasiswa Sosiologi aktif. Mereka diminta untuk menilai bagaimana layanan pendidikan Jurusan Sosiologi baik pada dosen, tenaga kependidikan, dan pengelola jurusan yang meliputi : keandalan, daya tanggap, kepastian/jaminan, empati dan kecukupan fasilitas serta aksesibilitas. Pendekatan yang digunakan dalam penelitian ini adalah pendekatan kuantitatif dengan jenis penelitian deskriptif. Populasi seluruh mahasiswa aktif angkatan 2012-2019 yang berkuliah di Jurusan Sosiologi Universitas Bengkulu yang berjumlah 336 Mahasiswa. Berdasarkan jumlah populasi, maka jumlah sampel dalam penelitian ini jika ditentukan berdasarkan tabel yang dikembangkan oleh Isaac dan Michael dengan taraf kesalahan 5\% adalah sebesar 172 sampel. Hasil hitung nilai rata-rata variabel aspek terkait layanan pendidikan Jurusan Sosiologi kepada pengguna (mahasiswa) pada kategori bagus. Aspek -aspek tersebut adalah : Keandalan, meliputi : Kemampuan dosen sebagai pengajar, nilai mean 6,56 = bagus), Kemampuan dosen sebagai pembimbing akademik, nilai mean $6,27=$ bagus), Kemampuan dosen sebagai pembimbing penyusunan skripsi, nilai mean $6,26=$ bagus) Keandalan staf, nilai mean $6,62=$ bagus Keandalan pengelola jurusan, nilai mean $=6,96$ Daya tanggap, nilai mean $6,80=$ bagus. Kepastian, nilai mean 6,65 = bagus Empati, nilai mean 7,12 = bagus. Tangible, nilai mean $6,70=$ bagus. Berdasarkan hasil hitung nilai rata-rata variabel pada poin 1 yang keseluruhannya pada kategori penilaian bagus serta penilaian responden yang mayoritas sangat baik terhadap semua pernyataan yang berkaitan dengan kepuasan pengguna terhadap layanan yang diberikan institusi, maka dapat disimpulkan bahwa mahasiswa merasa puas dengan layanan pendidikan yang diberikan oleh Jurusan Sosiologi
\end{abstract}

Kata Kunci: Kepuasan Mahasiswa, Layanan, Pendidikan 


\begin{abstract}
The focus of this research is the study of student satisfaction with the education and student services of the Department of Sociology. The research is aimed at active Sociology students. They were asked to assess how the Sociology Department's educational services are good for lecturers, education staff, and department managers which include: reliability, responsiveness, certainty/guarantee, empathy and adequacy of facilities and accessibility. The approach used in this research is a quantitative approach with descriptive research type. The population of all active students from the 2012-2019 class who study at the Sociology Department, Bengkulu University, is 336 students. Based on the total population, the number of samples in this study, if determined based on the table developed by Isaac and Michael with an error rate of 5\%, is 172 samples. The results of calculating the average value of aspects related to educational services for the Department of Sociology to users (students) are in the good category. These aspects are: Reliability, including: The ability of the lecturer as a teacher, the mean value is 6.56 $=$ good), the ability of the lecturer as an academic supervisor, the mean value is $6.27=$ good), the ability of the lecturer as a thesis supervisor, the mean value is 6, $26=$ good) Staff reliability, mean value 6,62 = good Reliability of department manager, mean value = 6,96 Responsiveness, mean value 6,80 = good. Certainty, the mean value is $6.65=$ good Empathy, the mean value is $7.12=$ good. Tangible, the mean value is $6.70=$ good. Based on the results of calculating the average value of the variables in point 1, all of which are in the good assessment category and the majority of respondents' assessments are very good on all statements related to user satisfaction with the services provided by the institution, it can be concluded that students are satisfied with the educational services provided. by the Department of Sociology.
\end{abstract}

\title{
Key Words: Student Satisfaction, Service Education
}

\section{PENDAHULUAN}

Dalam borang akreditasi Jurusan Sosiologi Tahun 2018 dijelaskan mengenai visi dan misi jurusan Sosiologi. Dalam naskah tersebut dijelaskan bahwa visi Jurusan Sosiologi adalah : menjadikan Program Sosiologi UNIB sebagai lembaga unggulan di bidang pendidikan dan pengajaran, penelitian dan publikasi serta pengabdian dan pengembangan masyarakat berlandaskan pada pemikiran kritis dan perilaku etis untuk menghasilkan lulusan yang memiliki kompetensi pembangunan masyarakat pesisir dan tepian hutan. Lebih lanjut dijelaskan untuk mencapai visi yang telah ditetapkan maka misi yang akan dilakukan adalah melaksanakan pendidikan dan pengajaran secara profesional berbasis kompetensi; membangun dan meningkatkan tata kelola program studi yang partisipatif, transparan dan akuntabel; melaksanakan penelitian tentang dinamika sosial, terutama pada masyarakat pesisir dan masyarakat sekitar kawasan hutan; melaksanakan pengabdian pada masyarakat yang berorientasi pada pemberdayaan dan 
pengembangan masyarakat, terutama pada masyarakat pesisir dan masyarakat sekitar kawasan hutan; menjalin kerjasama/kemitraan dengan instansi lain, baik pemerintah maupun swasta. Untuk mendukung visi dan misi jurusan tentunya dirumuskan pula tujuan yang hendak dicapai jurusan dalam proses belajar mengajar di jurusan Sosiologi. Adapun tujuannya sebagaimana tertera dalam borang tersebut adalah menghasilkan Sarjana Sosiologi yang memiliki kepekaan dan kepedulian sosial serta mampu menerapkan keahlian di bidang pengembangan masyarakat pesisir dan masyarakat sekitar kawasan hutan; menciptakan suasana akademik yang mendukung keberhasilan proses belajar-mengajar; menghasilkan penelitian dosen dan mahasiswa yang berkualitas dan bermanfaat bagi pembangunan masyarakat pesisir dan masyarakat sekitar kawasan hutan; menghasilkan Sarjana Sosiologi yang secara adaptif dan kompetitif mampu berperan sebagai agen perubahan sosial yang mengacu pada nilai-nilai moral; meningkatkan pengetahuan, kesadaran, dan keterampilan tentang kemandirian masyarakat dalam rangka penanggulangan kemiskinan di wilayah pesisir dan sekitar kawasan hutan.

Berdasarkan uraian tentang visi, misi dan tujuan dari Jurusan Sosiologi diatas, maka untuk mewujudkannya harus mempertimbangkan aspek kepuasan mahasiswa. Hal ini sangat penting karena mahasiswa merupakan konsumen utama dari Jurusan Sosiologi sebagai lembaga jasa pendidikan. Oleh karena itu dalam upaya meningkatkan kualitas pendidikan di Jurusan Sosiologi agar dapat menghasilkan lulusan yang memiliki daya saing dan dapat berkiprah dalam pembangunan maka salah satu indikator keberhasilan yang harus diperhatikan adalah aspek layanan pendidikan. Kualitas layanan pendidikan yang baik merupakan salah satu inti kelangsungan hidup sebuah lembaga. Jika lembaga pendidikan tidak memberikan layanan (pendidikan) yang berkualitas, bukan tidak mungkin pada saatnya akan ditinggalkan mahasiswanya lantaran mereka tidak mendapatkan sesuatu yang diharapkan.

Berbicara soal layanan pendidikan maka akan terkait dengan unsur pengelola jurusan, staf pengajar (dosen) dan tenaga kependidikannya yang merupakan bagian penting dari terciptanya layanan pendidikan yang berkualitas pada sebuah institusi jurusan. Untuk mengetahui bagaimana gambaran kualitas layanan pendidikan Jurusan Sosiologi menurut pandangan pengguna dalam hal ini adalah mahasiswa Jurusan Sosiologi, maka tim peneliti melakukan penelitian dengan tujuan memperoleh masukan (input) berupa penilaian mahasiswa terhadap layanan pendidikan Jurusan Sosiologi. Hal ini dianggap penting bagi Jurusan Sosiologi untuk secara berkala melakukan 
evaluasi terhadap layanan pendidikan dengan cara menjaring informasi dari penggunanya (mahasiswa), untuk selanjutnya dilakukan perbaikan-perbaikan guna meningkatkan mutu layanan dan sekaligus kualitas lembaga dalam memenuhi tuntutan perkembangan zaman.

Fokus penelitian ini adalah pengkajian mengenai kepuasan mahasiswa terhadap layanan pendidikan dan kemahasiswaan Jurusan Sosiologi. Penelitian ditujukan kepada mahasiswa Sosiologi aktif. Mereka diminta untuk menilai bagaimana layanan pendidikan Jurusan Sosiologi baik pada dosen, tenaga kependidikan, dan pengelola jurusan yang meliputi : keandalan, daya tanggap, kepastian/jaminan, empati dan kecukupan fasilitas serta aksesibilitas.

\section{METODE PENELITIAN}

Pendekatan yang digunakan dalam penelitian ini adalah pendekatan kuantitatif dengan jenis penelitian deskriptif. Populasi dalam penelitian sebanyak 339 mahasiswa angkatan 2012-2019 dan sampel pada populasi ini diperoleh berdasarkan kriteria Isaac dan Michael (Sugiyono, 2018 : 87) dengan taraf kesalahan 5\% sehingga dihasilkan 172 sampel. Penelitian ini dilakukan di Kota Bengkulu dan sasaran penelitiannya adalah mahasiswa aktif asal Jurusan Sosiologi Universitas Bengkulu.

Teknik pengumpulan data dalam penelitian ini adalah dengan menggunakan alat utama yaitu kuesioner. Pada proses pengumpulan data ada 212 responden yang mengisi kuesioner, maka total responden yang digunakan untuk dianalisis dalam penelitian ini adalah berjumlah 212 orang. Analisis data dilakukan untuk menjawab pertanyaanpertanyaan penelitian atau untuk menguji hipotesis-hipotesis penelitian yang telah dinyatakan sebelumnya. Data yang diperoleh disajikan dalam bentuk perhitungan statistik berbasis tendensi sentral, proporsi, persentase, dan penyajiannya melalui tabulasi distribusi tunggal maupun silang atau grafis. Kemudian peneliti mengukur tingkat kepuasan mahasiswa Jurusan Sosiologi terhadap layanan pendidikan (kinerja) Jurusan Sosiologi dengan menggunakan metode statistik deskriptif.

\section{PEMBAHASAN}

Kepuasan mahasiswa terhadap layanan pendidikan jurusan sosiologi, dalam implementasinya ialah dilaksanakan pada tahun 2020, penjangkauan atas survey ini 
menjadi komprehensif maka menjadi output yang kemudian menjadi saran dan agenda rutin jurusan sosiologi FISIP UNIB dalam memperoleh input berkala setiap waktunya.

Pada karakteristik responden dijelaskan ialah mahasiswa aktif yang berada pada angkatan 2012 hingga 2019, dimana hasil pengisian kuesioner diperoleh berdasarkan partisipasi mahasiswa/i yang aktif mengisi kuesioner secara online. Berdasarkan grafik dibawah ini dapat diketahui bahwa mayoritas responden merupakan angkatan aktif yaitu sebanyak 212 orang, dan yang menjadi spesifik ialah mahasiswa yang sedang menyusun skripsi, dalam angka partisipasi terlihat pada angkatan 2017 sejumlah 57 partisipasi mahasiswa yang mendominasi mengisi kuesioner.

\section{A.1. Karakteristik Responden}

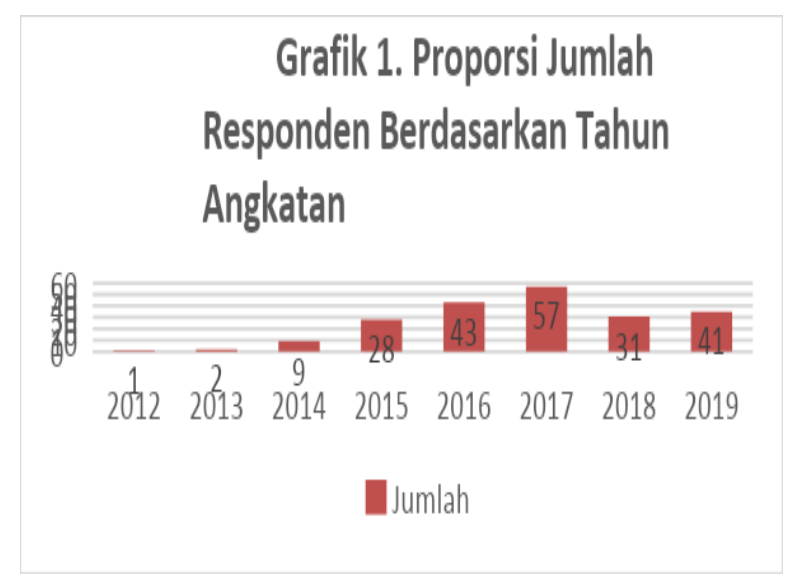

Sumber : Hasil Olah Data Primer, tahun 2020

\section{A.1.1. Kemampuan Dosen sebagai Pengajar}

Tabel 1. Analisis tentang Kemampuan Dosen Sebagai Pengajar

\begin{tabular}{|c|c|c|c|c|c|c|c|}
\hline No & Pernyataan & $\begin{array}{c}\text { Kurang } \\
(\%)\end{array}$ & $\begin{array}{l}\text { Cukup } \\
(\%)\end{array}$ & $\begin{array}{c}\text { Baik } \\
(\%)\end{array}$ & $\begin{array}{c}\text { Sangat } \\
\text { Baik } \\
(\%) \\
\end{array}$ & $\begin{array}{c}\text { Total } \\
(\%)\end{array}$ & Mean \\
\hline $\mathrm{c} 1$ & $\begin{array}{l}\text { Dosen yang mengajar } \\
\text { sesuai dengan Kompetensi } \\
\text { bidang keilmuan }\end{array}$ & $\begin{array}{c}5 \\
(2,365)\end{array}$ & $\begin{array}{c}2 \\
(0,94)\end{array}$ & $\begin{array}{c}51 \\
(24,06)\end{array}$ & $\begin{array}{l}154 \\
(72,64)\end{array}$ & $\begin{array}{l}212 \\
(100,00)\end{array}$ & 6,93 \\
\hline $\mathrm{c} 2$ & $\begin{array}{l}\text { Dosen yang mengajar } \\
\text { memberikan Kontrak } \\
\text { Perkuliahan yang telah } \\
\text { disepakati bersama dengan } \\
\text { Mahasiswa }\end{array}$ & $\begin{array}{c}4 \\
(1,89)\end{array}$ & $\begin{array}{c}5 \\
(2,36)\end{array}$ & $\begin{array}{c}43 \\
(20,28)\end{array}$ & $\begin{array}{c}160 \\
(75,47)\end{array}$ & $\begin{array}{c}212 \\
(100,00)\end{array}$ & 7,07 \\
\hline c3 & $\begin{array}{lr}\text { Dosen yang } & \text { mengajar } \\
\text { memberikan } & \text { Silabus } \\
\text { perkuliahan } & \text { kepada } \\
\text { mahasiswa } & \\
\end{array}$ & $\begin{array}{c}5 \\
(2,36)\end{array}$ & $\begin{array}{c}5 \\
(2,36)\end{array}$ & $\begin{array}{c}58 \\
(27,36)\end{array}$ & $\begin{array}{c}144 \\
(67,92)\end{array}$ & $\begin{array}{l}212 \\
(100,00)\end{array}$ & 6,83 \\
\hline
\end{tabular}




\begin{tabular}{|c|c|c|c|c|c|c|c|}
\hline $\mathrm{c} 4$ & $\begin{array}{l}\text { Dosen yang mengajar } \\
\text { memberikan perkuliahan } \\
\text { sesuai dengan silabus yang } \\
\text { diberikan }\end{array}$ & $(1,89)^{4}$ & $\begin{array}{c}5 \\
(2,36)\end{array}$ & $\begin{array}{c}56 \\
(26,42)\end{array}$ & $\begin{array}{l}147 \\
(69,34)\end{array}$ & $\begin{array}{l}212 \\
(100,00)\end{array}$ & 6,88 \\
\hline c5 & $\begin{array}{l}\text { Dosen yang mengajar } \\
\text { memberikan umpan balik } \\
\text { secara baik dan benar }\end{array}$ & $\begin{array}{r}4 \\
(1,89)\end{array}$ & $\begin{array}{c}5 \\
(2,36)\end{array}$ & $\begin{array}{l}45 \\
(21,23)\end{array}$ & $\begin{array}{l}158 \\
(74,53)\end{array}$ & $\begin{array}{c}212 \\
(100,00)\end{array}$ & 6,91 \\
\hline c6 & $\begin{array}{lrr}\text { Dosen yang } & \text { mengajar } \\
\text { memberikan umpan balik } \\
\text { pada setiap aktivitas } \\
\text { diskusi }\end{array}$ & $\begin{array}{c}4 \\
(1,89)\end{array}$ & $\begin{array}{c}4 \\
(1,89)\end{array}$ & $\begin{array}{l}49 \\
(23,11)\end{array}$ & $\begin{array}{c}155 \\
(73,11)\end{array}$ & $\begin{array}{l}212 \\
(100,00)\end{array}$ & 6,98 \\
\hline c7 & $\begin{array}{l}\text { Dosen yang mengajar } \\
\text { memberikan umpan balik } \\
\text { pada setiap tugas yang } \\
\text { diberikan }\end{array}$ & $\begin{array}{c}4 \\
(1,89)\end{array}$ & $\begin{array}{c}5 \\
(2,36)\end{array}$ & $\begin{array}{c}58 \\
(27,36)\end{array}$ & $\begin{array}{l}145 \\
(68,40)\end{array}$ & $\begin{array}{l}212 \\
(100,00)\end{array}$ & 6,81 \\
\hline c8 & $\begin{array}{l}\text { Dosen yang mengajar } \\
\text { memberikan nilai yang } \\
\text { sesuai dengan hasil belajar }\end{array}$ & $\begin{array}{c}5 \\
(2,36)\end{array}$ & $\begin{array}{c}11 \\
(5,19)\end{array}$ & $\begin{array}{c}67 \\
(31,60)\end{array}$ & $\begin{array}{c}129 \\
(60,85)\end{array}$ & $\begin{array}{c}212 \\
(100,00)\end{array}$ & 6,55 \\
\hline c9 & $\begin{array}{l}\text { Dosen mengajar tepat } \\
\text { waktu }\end{array}$ & $\begin{array}{c}4 \\
(1,89)\end{array}$ & $\begin{array}{c}13 \\
(6,13)\end{array}$ & $\begin{array}{c}80 \\
(37,74)\end{array}$ & $\begin{array}{c}115 \\
(54,25)\end{array}$ & $\begin{array}{c}212 \\
(100,00)\end{array}$ & 6,43 \\
\hline $\mathrm{c} 10$ & $\begin{array}{l}\text { Dosen yang mengajar } \\
\text { menggunakan teknologi } \\
\text { (infokus) dalam proses } \\
\text { pembelajaran }\end{array}$ & $\begin{array}{c}3 \\
(1,42)\end{array}$ & $\begin{array}{c}5 \\
(2,36)\end{array}$ & $\begin{array}{c}61 \\
(28,77)\end{array}$ & $\begin{array}{c}143 \\
(67,45)\end{array}$ & $\begin{array}{c}212 \\
(100,00)\end{array}$ & 6,79 \\
\hline c11 & $\begin{array}{lrr}\text { Dosen yang } & \text { mengajar } \\
\text { berlaku adil } & \text { kepada } \\
\text { mahasiswa } & \\
\end{array}$ & $\begin{array}{c}5 \\
(2,36)\end{array}$ & $\begin{array}{c}9 \\
(4,25)\end{array}$ & $\begin{array}{c}59 \\
(27,83)\end{array}$ & $\begin{array}{c}139 \\
(65,57)\end{array}$ & $\begin{array}{c}212 \\
(100,00)\end{array}$ & 6,73 \\
\hline c12 & $\begin{array}{l}\text { Dosen yang mengajar } \\
\text { memiliki toleransi kepada } \\
\text { mahasiswa }\end{array}$ & $\begin{array}{c}2 \\
(0,94)\end{array}$ & $\begin{array}{c}5 \\
(2,36)\end{array}$ & $\begin{array}{c}53 \\
(25,00)\end{array}$ & $\begin{array}{c}152 \\
(71,70)\end{array}$ & $\begin{array}{c}212 \\
(100,00)\end{array}$ & 6,55 \\
\hline $\mathrm{c} 13$ & $\begin{array}{l}\text { Ada reward /penghargaan } \\
\text { yang diberikan dosen pada } \\
\text { mahasiswa dalam proses } \\
\text { belajar }\end{array}$ & $\begin{array}{c}8 \\
(3,77)\end{array}$ & $\begin{array}{c}17 \\
(8,02)\end{array}$ & $\begin{array}{c}83 \\
(39,15)\end{array}$ & $\begin{array}{c}104 \\
(49,06)\end{array}$ & $\begin{array}{c}212 \\
(100,00)\end{array}$ & 6,19 \\
\hline c14 & $\begin{array}{l}\text { Ada punishment / sanksi } \\
\text { yang jelas yang diberikan } \\
\text { dosen pada mahasiswa } \\
\text { dalam proses belajar }\end{array}$ & $\begin{array}{c}1 \\
(0,47)\end{array}$ & $\begin{array}{c}15 \\
(7,08)\end{array}$ & $\begin{array}{c}62 \\
(29,25)\end{array}$ & $\begin{array}{c}134 \\
(63,21)\end{array}$ & $\begin{array}{c}212 \\
(100,00)\end{array}$ & 6,66 \\
\hline c15 & $\begin{array}{l}\text { Dosen menjalankan peran } \\
\text { sebagai fasilitator di } \\
\text { perkuliahan lapangan bagi } \\
\text { mahasiswa }\end{array}$ & $\begin{array}{c}38 \\
(17,92)\end{array}$ & $\begin{array}{c}37 \\
(17,45)\end{array}$ & $\begin{array}{c}61 \\
(28,77)\end{array}$ & $\begin{array}{c}76 \\
(35,85)\end{array}$ & $\begin{array}{c}212 \\
(100,00)\end{array}$ & 5,18 \\
\hline c16 & $\begin{array}{l}\text { Dosen mendampingi } \\
\text { diskusi atas permasalahan } \\
\text { kuliah yang ditemui oleh } \\
\text { mahasiswa }\end{array}$ & $\begin{array}{c}14 \\
(6,60)\end{array}$ & $\begin{array}{c}24 \\
(11,32)\end{array}$ & $\begin{array}{c}74 \\
(34,91)\end{array}$ & $\begin{array}{c}100 \\
(47,17)\end{array}$ & $\begin{array}{c}212 \\
(100,00)\end{array}$ & 5,96 \\
\hline c17 & $\begin{array}{l}\text { Dosen yang mengajar } \\
\text { melakukan inovasi dalam } \\
\text { metode pembelajaran }\end{array}$ & $\begin{array}{c}14 \\
(6,60)\end{array}$ & $\begin{array}{c}25 \\
(11,79)\end{array}$ & $\begin{array}{c}68 \\
(32,08)\end{array}$ & $\begin{array}{c}105 \\
(49,53)\end{array}$ & $\begin{array}{c}212 \\
(100,00)\end{array}$ & 6,05 \\
\hline
\end{tabular}

\section{Sumber : Hasil Olah Data Primer, tahun 2020}

Berdasarkan data pada tabel 1 dapat disimpulkan bahwa mayoritas responden menilai sangat baik terhadap kemampuan dosen Sosiologi sebagai pengajar. Pada indikator ke-1 didapat nilai rata-rata 6,93. Ini artinya mahasiswa menilai pada kategori 
bagus maka nilai rata-rata mean secara keseluruhan yaitu 6,56 sehingga dapat disimpulkan bahwa kemampuan dosen Sosiologi sebagai pengajar pada kategori bagus.

\section{A.1.2. Kemampuan Dosen sebagai Pembimbing Akademik}

Berdasarkan data pada tabel 2, dapat kita ketahui bahwa mayoritas responden memberikan jawaban sangat baik pada setiap indikator pernyataan yang ada. Pada pertanyaan pertama (d1), 5 orang responden memilih kurang, ini artinya pertemuannya dengan dosen pembimbing akademik antara 1-2 kali dalam satu semester. Lalu 9 orang responden menjawab cukup, itu berarti pertemuannya dengan dosen pembimbing akademik antara 3-4 kali. 42 responden menjawab baik, artinya dalam satu semester responden bertemu dengan dosen pembimbing akademiknya sebanyak 5-6 kali. Dan yang terakhir 157 responden $(74,06 \%)$ menjawab sangat baik, artinya ia berkonsultasi dengan dosen pembimbing akademiknya lebih dari 6 kali dalam satu semester. Setelah dihitung nilai rata-ratanya didapat angka 6,97 itu artinya intensitas pertemuan mahasiswa dengan dosen pembimbing akademiknya pada kategori bagus. Yaitu lebih dari 6 kali dalam satu semester.

Tabel 2. Analisis Penilaian Responden tentang Kemampuan Dosen

Sebagai Pembimbing Akademik

\begin{tabular}{|c|c|c|c|c|c|c|c|}
\hline No & Pertanyaan & Kurang & Cukup & Baik & Sangat Baik & Total & Mean \\
\hline $\mathrm{d} 1$ & $\begin{array}{l}\text { Berapa kali per semester saudara } \\
\text { berdialog dengan Dosen Pembimbing } \\
\text { Akademik? }\end{array}$ & $5(2,36 \%)$ & $9(4,24 \%)$ & $41(19,34 \%)$ & $157(74,06 \%)$ & 212 & 6,97 \\
\hline$d 2$ & $\begin{array}{l}\text { Dosen dan saudara menjalin hubungan } \\
\text { yang akrab }\end{array}$ & $12(5,66 \%)$ & $18(8,49 \%)$ & $54(25,47 \%)$ & $128(60,37 \%)$ & 212 & 6,37 \\
\hline d3 & $\begin{array}{l}\text { Dosen dan saudara me lakukan dialog- } \\
\text { dialog langsung dalam masalah akademik }\end{array}$ & $13(6,13 \%)$ & $23(10,85 \%)$ & $64(30,19 \%)$ & $112(52,83 \%)$ & 212 & 6,12 \\
\hline d4 & $\begin{array}{l}\text { Dosen menandatangani Kartu Rencana } \\
\text { Studi saudara, baik online maupun offline }\end{array}$ & $21(9,90)$ & $24(11,32 \%)$ & $83(39,15 \%)$ & $84(39,62 \%)$ & 212 & 5,64 \\
\hline d5 & $\begin{array}{l}\text { Ketekunan Dosen membina saudara } \\
\text { untuk keberhasilan dan penyelesaian } \\
\text { studi }\end{array}$ & $10(4,72 \%)$ & $24(11,32 \%)$ & $70(33,02 \%)$ & $108(50,94 \%)$ & 212 & 6,16 \\
\hline d6 & Dosen peduli pada keadaan saudara & $10(4,72 \%)$ & $23(10,85 \%)$ & $65(30,66 \%)$ & $114(53,77 \%)$ & 212 & 6,26 \\
\hline d7 & Dosen sensitif pada keadaan saudara & $14(6,60 \%)$ & $15(7,07 \%)$ & $56(26,41 \%)$ & $127(59,90 \%)$ & 212 & 6,37 \\
\hline d8 & $\begin{array}{l}\text { Dosen cukup bijak menerima kondisi } \\
\text { saudara apa adanya }\end{array}$ & $10(4,72 \%)$ & $23(10,85 \%)$ & $67(31,60 \%)$ & $112(52,83 \%)$ & 212 & 6,24 \\
\hline d9 & $\begin{array}{l}\text { Saudara mengkonsultasikan masalah non } \\
\text { akademik pada Dosen }\end{array}$ & $11(5,19 \%)$ & $16(7,55 \%)$ & $69(32,55 \%)$ & $116(54,72 \%)$ & 212 & 6,28 \\
\hline
\end{tabular}

Sumber : Hasil Olah Data Primer, tahun 2020 
Berdasarkan pemaparan data-data di atas maka nilai rata-rata mean secara keseluruhan yaitu 6,27, sehingga dapat disimpulkan bahwa kemampuan dosen Sosiologi sebagai dosen pembimbing akademik pada kategori bagus.

\section{A.1.3. Kemampuan Dosen Selaku Pembimbing Penyusunan Skripsi}

Tabel 3. Analisis Penilaian Responden tentang Kemampuan Dosen Selaku Pembimbing Penyusunan Skripsi

\begin{tabular}{|c|c|c|c|c|c|c|c|}
\hline No & Pernyataan & Kurang & Cukup & Baik & Sangat Baik & TOTAL & Mean \\
\hline e 1 & $\begin{array}{l}\text { Dosen pembimbing memberikan waktu } \\
\text { (jadwal) untuk anda berkonsultasi mengenai } \\
\text { skripsi anda }\end{array}$ & $5(6,02 \%)$ & $6(7,23 \%)$ & $30(36,14 \%)$ & $42(50,60 \%)$ & $83 / 100 \%$ & 6,14 \\
\hline e2 & $\begin{array}{l}\text { Anda dan dosen pembimbing dapat } \\
\text { berkomunikasi dengan baik dalam proses } \\
\text { pembimbingan }\end{array}$ & $5(6,02 \%)$ & $7(8,43 \%)$ & $27(32,53 \%)$ & $44(53,01)$ & $83 / 100 \%$ & 6,14 \\
\hline e3 & $\begin{array}{l}\text { Proses pembimbingan skripsi dengan dosen } \\
\text { pembimbing berjalan baik/lancar }\end{array}$ & $4(4,82 \%)$ & $7(8,43 \%)$ & $30(36,14 \%)$ & $42(50,60 \%)$ & $83 / 100 \%$ & 6,19 \\
\hline e4 & $\begin{array}{l}\text { Kearifan Dosen dalam membimbing sesuai } \\
\text { dengan kondisi saudara }\end{array}$ & $5(6,02 \%)$ & $7(8,43 \%)$ & $31(37,35 \%)$ & $40(48,19 \%)$ & $83 / 100 \%$ & 6,07 \\
\hline e 5 & $\begin{array}{l}\text { Anda tidak kesulitan dalam menyepakati } \\
\text { jadwal seminar skripsi dengan dosen } \\
\text { pembimbing }\end{array}$ & $1(1,20 \%)$ & $5(6,02 \%)$ & $28(33,73 \%)$ & $49(59,04 \%)$ & $83 / 100 \%$ & 6,47 \\
\hline e6 & $\begin{array}{l}\text { Anda tidak kesulitan dalam menyepakati } \\
\text { jadwal ujian skripsi dengan dosen } \\
\text { pembimbing }\end{array}$ & $1(1,20 \%)$ & $3(3,61 \%)$ & $29(34,94 \%)$ & $50(60,24 \%)$ & $83 / 100 \%$ & 6,53 \\
\hline e7 & $\begin{array}{l}\text { Anda tidak kesulitan dalam menyepakati } \\
\text { jadwal seminar hasil skripsi dengan dosen } \\
\text { penguji }\end{array}$ & $1(1,20 \%)$ & $3(3,61 \%)$ & $28(33,73 \%)$ & $51(61,44 \%)$ & $83 / 100 \%$ & 6,68 \\
\hline e8 & $\begin{array}{l}\text { Anda tidak kesulitan dalam menyepakati } \\
\text { jadwal ujian skripsi dengan dosen penguji }\end{array}$ & $5(6,02 \%)$ & $12(14,46 \%)$ & $34(40,96 \%)$ & $32(38,55 \%)$ & $83 / 100 \%$ & 5,79 \\
\hline
\end{tabular}

Sumber : Hasil Olah Data Primer, tahun 2020

Berdasarkan pemaparan data-data di atas maka nilai rata-rata mean secara keseluruhan yaitu 6,26, sehingga dapat disimpulkan bahwa kemampuan dosen selaku pembimbing penyusunan skripsi pada kategori bagus.

\section{A.1.3 Keandalan Staf Jurusan}

Tabel 4 menunjukkan bahwa mayoritas responden menilai sangat baik pengetahuan staf di Jurusan Sosiologi. Menurut responden staf Jurusan Sosiologi telah memiliki pengetahuan yang memadai di bidangnya. Indikatornya staf dapat memberikan informasi terkait dengan kebutuhan administrasi mahasiswa, seperti informasi pendataan mahasiswa, pengisian KRS, pengajuan cuti, peraturan akademik serta informasi akademik. Nilai mean untuk poin ini adalah 6,73, itu artinya pengetahuan staf jurusan Sosiologi dinilai telah memadai di bidangnya. 
Tabel 4. Analisis Penilaian Responden tentang Keandalan Staf Jurusan Sosiologi dalam Layanan Pendidikan

\begin{tabular}{|c|c|c|c|c|c|c|c}
\hline No & \multicolumn{1}{|c|}{ Pertanyaan } & Kurang & Cukup & Baik & Sangat Baik & Total & Mean \\
\hline fl & $\begin{array}{l}\text { Pengetahuan stafmemadai di } \\
\text { bidangnya }\end{array}$ & $4(1,88 \%)$ & $10(4,72 \%)$ & $59(27,83 \%)$ & $139(65,57 \%)$ & $212(100 \%)$ & 6,73 \\
\hline f2 & $\begin{array}{l}\text { Kemampuan stafmemadai di } \\
\text { bidangnya }\end{array}$ & $7(3,30 \%)$ & $12(5,66 \%)$ & $63(29,72 \%)$ & $130(61,32 \%)$ & $212(100 \%)$ & 6,52 \\
\hline
\end{tabular}

Sumber : Hasil Olah Data Primer, tahun 2020

Begitu pun dengan kemampuan yang dimiliki oleh staf jurusan, ia telah mampu mengaplikasi apa yang diketahuinya. Terutama dalam hal pengurusan administrasi. Nilai mean untuk poin kemampuan staf ini yaitu 6,52, artinya kemampuan staf berada pada kategori bagus. Berdasarkan pemaparan data-data di atas maka nilai rata-rata mean secara keseluruhan yaitu 6,62 sehingga dapat disimpulkan bahwa keandalan Staf Jurusan Sosiologi dalam Layanan Pendidikan pada kategori bagus.

\section{A.1.4 Keandalan Pengelola Jurusan}

Tabel 4. Analisis Penilaian Responden tentang Keandalan Pengelola Jurusan Sosiologi dalam Layanan Pendidikan

\begin{tabular}{|c|c|c|c|c|c|c|c}
\hline No & \multicolumn{1}{|c|}{ Pertanyaan } & Kurang & Cukup & Baik & Sangat Baik & Total & Mean \\
\hline f3 & $\begin{array}{l}\text { Jurusan memiliki prosedur } \\
\text { yang jelas dalam } \\
\text { Pembimbingan Akademik }\end{array}$ & $4(1,88 \%)$ & $8(3,77 \%)$ & $71(33,49 \%)$ & $129(60,85 \%)$ & $212(100 \%)$ & 6,64 \\
\hline f4 & $\begin{array}{l}\text { Jurusan memiliki prosedur } \\
\text { yang jelas terkait Seminar } \\
\text { Proposal, Seminar Hasil dan } \\
\text { Sidang skripsi }\end{array}$ & $3(1,41 \%)$ & $5(2,36 \%)$ & $24(11,32 \%)$ & $180(84,90 \%)$ & $212(100 \%)$ & 7,29 \\
\hline
\end{tabular}

Sumber : Hasil Olah Data Primer, tahun 2020

Pada tabel 4 dijelaskan jawaban responden mengenai keandalan pengelola jurusan Sosiologi dalam hal kepemilikan prosedur yang jelas dalam pembimbingan akademik dan terkait seminar proposal, seminar hasil dan sidang skripsi. Menurut mayoritas responden pengelola jurusan Sosiologi telah mempunyai dan melaksanakan prosedur akademik dengan sangat baik (129 orang/60,58\%). Selama ini pengelola jurusan Sosiologi berupaya selalu mengacu kepada aturan universitas yang tertuang dalam STATUTA dan peraturan-peraturan rektor lainnya. Namun belum ada SOP jurusan yang 
khusus mengatur soal proses pembimbingan akademik. Jika ada satu kondisi yang cukup pelik, maka biasanya pengelola jurusan selain mengacu pada aturan dan STATUTA UNIB juga melibatkan para dosen untuk sharing mengambil keputusan bersama dalam memutuskan sebuah kebijakan internal jurusan.

Berdasarkan pemaparan data-data di atas maka nilai rata-rata mean secara keseluruhan yaitu 6,96 sehingga dapat disimpulkan bahwa keandalan pengelola Jurusan Sosiologi dalam Layanan Pendidikan pada kategori bagus.

\section{B. Daya Tanggap}

Jika dilihat berdasarkan nilai mean (rata-rata hitung) pada tabel 5 maka dapat diketahui bahwa mayoritas responden menilai sangat baik terhadap semua indikator daya tanggap Jurusan Sosiologi dalam memberikan pelayanan akademik. Namun dari keempat indikator daya tanggap tersebut, indikator ketiga (g4) merupakan yang tertinggi nilainya, yaitu pilihan responden terbanyak dan nilai mean rata-rata terbesar, dipilih 165 responden dan dengan nilai mean 7,04. Ini artinya pelayanan yang diberikan oleh staf jurusan Sosiologi sudah bagus, telah sesuai dengan harapan pengguna yaitu baik dan cepat. Begitu pun dengan poin melayani keperluan administrasi secara lengkap yang dilakukan oleh jurusan, telah dinilai bagus oleh responden (147 orang/69,33\%) dengan nilai mean 6,61 .

Tabel 5. Analisis Penilaian Responden tentang Daya Tanggap Jurusan Sosiologi dalam Memberikan Layanan Pendidikan

\begin{tabular}{|c|l|c|c|c|c|c|c|}
\hline No & Pertanyaan & Kurang & Cukup & Baik & Sangat Baik & Total & Mean \\
\hline g1 & $\begin{array}{l}\text { Kemudahan dalam } \\
\text { berkomunikasi dengan Dosen } \\
\text { menggunakan media sosial yang } \\
\text { tersedia }\end{array}$ & $3(1,41 \%)$ & $6(2,83 \%)$ & $42(19,81 \%)$ & $161(75,94 \%)$ & $212(100 \%)$ & 7 \\
\hline g2 & $\begin{array}{l}\text { Staf jurusan melayani keperluan } \\
\text { administrasi secara lengkap }\end{array}$ & $8(3,77 \%)$ & $9(4,24 \%)$ & $48(22,64 \%)$ & $147(69,33 \%)$ & $212(100 \%)$ & 6,61 \\
\hline $\mathrm{g} 3$ & $\begin{array}{l}\text { Staf Jurusan Sosiologi } \\
\text { memberikan pelayanan secara } \\
\text { baik dan cepat }\end{array}$ & $5(2,36 \%)$ & $4(1,88 \%)$ & $38(17,92 \%)$ & $165(77,83 \%)$ & $212(100 \%)$ & 7,04 \\
\hline $\mathrm{g} 4$ & $\begin{array}{l}\text { Jurusan melakukan monitoring } \\
\text { dan evaluasi dalam } \\
\text { penyelenggaran kegiatan } \\
\text { akademik }\end{array}$ & $7(3,30 \%)$ & $13(6,13 \%)$ & $56(26,41 \%)$ & $136(64,15 \%)$ & $212(100 \%)$ & 6,58 \\
\hline
\end{tabular}

Sumber : Hasil Olah Data Primer, tahun 2020

Sedangkan daya tanggap dari dosen dan pengelola jurusan Sosiologi juga dinilai sangat baik oleh responden. 161 responden menilai sangat baik kemudahan dalam berkomunikasi dengan Dosen menggunakan media sosial yang tersedia, lalu 136 
responden menilai Jurusan sangat baik dalam melakukan monitoring dan evaluasi dalam penyelenggaraan kegiatan akademik. Nilai mean dari daya tanggap dosen Sosiologi yaitu 7 dan jurusan Sosiologi yakni 7. Keduanya merupakan kategori bagus. Artinya mahasiswa menilai bahwa daya tanggap dosen dalam berkomunikasi dengan mahasiswa sudah bagus. Begitupun daya tanggap jurusan dalam monitoring dan evaluasi dalam penyelenggaraan akademik pun sudah demikian. Contoh dari indikator ini seperti : aturan baru tentang kurikulum merdeka belajar, jurusan merespon cepat dengan cara menyelenggarakan kegiatan rapat untuk mengkaji kurikulum ini. Dan alhasil jurusan Sosiologi sudah menetapkan aturan mekanisme dalam penyelenggaraan kurikulum merdeka belajar ini. Lalu peraturan tentang PIN nasional untuk ijazah kelulusan yang akan diterapkan tahun depan. Jurusan Sosiologi berupaya mengantisipasi dengan cara mengundang seluruh mahasiswa yang akan menjadi calon terdampak dari peraturan ini lalu memberikan gambaran dan solusi terkait hal ini.Berdasarkan pemaparan data-data di atas maka nilai rata-rata mean secara keseluruhan yaitu 6,80 sehingga dapat disimpulkan bahwa daya tanggap Jurusan Sosiologi dalam memberikan layanan pendidikan pada kategori bagus.

\section{Kepastian}

Berdasarkan tabel 6 dapat diketahui bahwa mayoritas responden menjawab sangat baik untuk pertanyaan dosen berpenampilan rapi dan sopan ketika mengajar (145 orang/68,40\%). Nilai mean yang diperoleh 6,65 , artinya dosen sudah berpenampilan bagus ketika mengajar. Indikatornya dosen selalu berpenampilan rapi dan sopan saat mengajar.

Tabel 6. Analisis Penilaian Responden tentang Kepastian Layanan Pendidikan

\begin{tabular}{|c|c|c|c|c|c|c|c|}
\hline No & Pertanyaan & Kurang & Cukup & Baik & Sangat Baik & Total & Mean \\
\hline h1 & $\begin{array}{l}\text { Dosen berpenampilan rapi dan } \\
\text { sopan ketika mengajar }\end{array}$ & $6(2,83 \%)$ & $12(5,66 \%)$ & $49(23,11 \%)$ & $145(68,40 \%)$ & $212(100 \%)$ & 6,65 \\
\hline h2 & $\begin{array}{l}\text { Dosen bersikap ramah dalam } \\
\text { berkomunikasi dengan } \\
\text { mahasiswa }\end{array}$ & $6(2,83 \%)$ & $16(7,55 \%)$ & $52(24,53 \%)$ & $138(65,09 \%)$ & $212(100 \%)$ & 6,56 \\
\hline h3 & $\begin{array}{l}\text { Dosen memberikan penilaian } \\
\text { akhir kemahasiswa dengan } \\
\text { sangat transparan }\end{array}$ & $7(3,30 \%)$ & $16(7,55 \%)$ & $56(26,42 \%)$ & $133(62,74 \%)$ & $212(100 \%)$ & 6,5 \\
\hline $\mathrm{h} 4$ & $\begin{array}{l}\text { Dosen memberikan teguran } \\
\text { kepada mahasiswa yang tidak } \\
\text { sesuai dengan kontrak } \\
\text { perkuliahan }\end{array}$ & $10(4,72 \%)$ & $9(4,25 \%)$ & $69(32,55 \%)$ & $124(58,49 \%)$ & $212(100 \%)$ & 6,41 \\
\hline h5 & $\begin{array}{l}\text { Staf Jurusan bersikap ramah } \\
\text { dalam melayani mahasiswa }\end{array}$ & $7(3,30 \%)$ & $14(6,60 \%)$ & $55(25,94 \%)$ & $136(64,15 \%)$ & $212(100 \%)$ & 6,55 \\
\hline h6 & $\begin{array}{l}\text { Staf Jurusan dapat sering ditemui } \\
\text { mahasiswa pada saat jam kerja }\end{array}$ & $2(0,94 \%)$ & $5(2,36 \%)$ & $32(15,09 \%)$ & $173(81,60 \%)$ & $212(100 \%)$ & 7,21 \\
\hline
\end{tabular}

Sumber : Hasil Olah Data Primer, tahun 2020 
Lalu pada pertanyaan berikutnya, menurut mayoritas responden dosen Sosiologi bersikap ramah dalam berkomunikasi dengan mahasiswa (138 orang/65,09\%). Nilai ratarata hitung pada poin ini adalah 6,56. Artinya dosen sudah bersikap sangat baik terhadap mahasiswa dalam berkomunikasi. Berdasarkan pemaparan data-data di atas maka nilai rata-rata mean secara keseluruhan yaitu 6,65 sehingga dapat disimpulkan bahwa aspek kepastian dari Jurusan Sosiologi dalam memberikan layanan pendidikan pada kategori bagus.

\section{Empati}

Pada bagian ini dijelaskan mengenai sikap empati Jurusan Sosiologi dalam memberikan pelayanan pendidikan kepada pengguna (mahasiswa). Yang dimaksud dengan Jurusan Sosiologi disini bukan hanya berkaitan dengan institusi, tetapi juga termasuk unsur-unsur yang ada didalamnya, seperti dosen dan staf jurusan.

Pada pertanyaan pertama, mayoritas responden menjawab sangat baik dalam hal dosen membuka ruang berdiskusi terkait masalah akademik dengan mahasiswa. Ada 168 orang yang menilai bahwa dosen sudah membuka ruang berdiskusi dengan mahasiswa terkait masalah akademik. Nilai-nilai rata-rata hitung yang diperoleh yakni 7,13. Artinya dosen sudah bagus dalam membuka ruang diskusi dengan mahasiswanya terkait masalah akademik. Ruang diskusi yang disediakan dosen Sosiologi tidak hanya dalam ruang perkuliahan semata, tetapi dosen pun bersedia jika mahasiswa ingin berdiskusi di ruang perkuliahan. Masalah akademik yang biasa didiskusikan oleh mahasiswa selain materi perkuliahan adalah terkait dengan tema-tema rencana judul penelitian, lalu rencana mata kuliah yang akan diambil oleh mahasiswa, dan sebagainya.

Tabel 7. Analisis Penilaian Responden tentang Empati Jurusan Sosiologi dalam Pelayanan Pendidikan

\begin{tabular}{|c|l|c|c|c|c|c|c}
\hline No & \multicolumn{1}{|c|}{ Pertanyaan } & Kurang & Cukup & Baik & Sangat Baik & Total & Mean \\
\hline i1 & $\begin{array}{l}\text { Dosen membuka ruang } \\
\text { berdiskusi terkait masalah } \\
\text { akademik dengan mahasiswa }\end{array}$ & $3(1,42 \%)$ & $5(2,36 \%)$ & $36(16,98 \%)$ & $168(79,25 \%)$ & $212(100 \%)$ & 7,13 \\
\hline i2 & $\begin{array}{l}\text { Informasi dan layanan website } \\
\text { jurusan sosiologi memberikan } \\
\text { kemudahan bagi mahasiswa }\end{array}$ & $2(0,94 \%)$ & $6(2,83 \%)$ & $42(19,81 \%)$ & $162(76,42 \%)$ & $212(100 \%)$ & 7,08 \\
\hline i3 & $\begin{array}{l}\text { Kepedulian staf dalam } \\
\text { menyelesaikan masalah } \\
\text { mahasiswa }\end{array}$ & $2(0,94 \%)$ & $5(2,36 \%)$ & $35(16,51 \%)$ & $170(80,19 \%)$ & $212(100 \%)$ & 7,16 \\
\hline i4 & $\begin{array}{l}\text { Stafberlaku adil dalam } \\
\text { memberikan layanan kepada } \\
\text { mahasiswa }\end{array}$ & $2(0,94 \%)$ & $4(1,89 \%)$ & $40(18,87 \%)$ & $166(78,30 \%)$ & $212(100 \%)$ & 7,14 \\
\hline
\end{tabular}


Pada pertanyaan berikutnya tentang informasi dan layanan website jurusan Sosiologi dalam hal memberikan kemudahan bagi mahasiswa. Mayoritas responden menjawab sangat baik (162 orang/76,42\%) pada poin ini. Nilai rata-rata hitung yang diperoleh 7,08. Artinya website jurusan Sosiologi sudah bagus dalam memberikan kemudahan bagi mahasiswa. Melalui website ini mahasiswa memperoleh informasi terupdate dan penting terkait jurusan maupun universitas.

Berikutnya, tentang kepedulian staf dalam menyelesaikan masalah mahasiswa. Menurut mayoritas responden (170 orang/80,19\%) kepedulian staf dalam menyelesaikan masalah (administrasi) mahasiswa sangat baik. Nilai rata-rata hitung yang diperoleh 7,16. Artinya staf jurusan sudah bagus dalam hal kepeduliannya menyelesaikan masalah (administrasi) mahasiswa.

Terakhir, tentang staf berlaku adil dalam memberikan layanan kepada mahasiswa. Mayoritas responden menjawab sangat baik terhadap pertanyaan pada poin ini. Ada 166 orang responden $(78,30 \%)$ yang memberikan penilaian sangat baik. Nilai rata-rata hitung yang diperoleh sebesar 7,14. Artinya menurut mahasiswa perilaku adil staf jurusan dalam memberikan pelayanan kepada mahasiswa sudah bagus. Perilaku adil staf jurusan ditunjukkan dengan bergiliran melayani mahasiswa sesuai dengan antriannya.

Berdasarkan pemaparan data-data di atas maka nilai rata-rata mean secara keseluruhan yaitu 7,12 sehingga dapat disimpulkan bahwa empati Jurusan Sosiologi dalam memberikan layanan pendidikan pada kategori bagus.

\section{E. Tangible}

Pada bagian ini dijelaskan penilaian responden mengenai aspek tangible dalam Jurusan Sosiologi. Aspek ini terkait dengan ketersediaan fasilitas yang ada di Jurusan Sosiologi UNIB.

Aspek tangible yang dinilai oleh mahasiswa yaitu kebersihan kantor Jurusan Sosiologi, mayoritas menilai sangat baik mengenai kebersihan jurusan Sosiologi. Begitu pula dengan kerapian kantor Jurusan Sosiologi. Terkait dengan kebersihan dan kerapian kantor jurusan, fakultas telah memfasilitasi petugas kebersihan yang bertugas untuk membersihkan dan merapikan kantor. Selain itu civitas akademika Sosiologi juga ikut serta dalam menjaga kebersihan dan kerapian kantor dengan cara membuang sampah pada tempat yang telah disediakan, menjaga kerapian ruangan masing-masing dosen. Sehingga akhirnya tercipta kantor Jurusan Sosiologi yang nyaman. Dan mayoritas responden menilai bahwa kondisi kantor Jurusan Sosiologi pada kategori bagus, yaitu 
bersih, rapi dan nyaman.Berdasarkan pemaparan data-data di atas maka nilai rata-rata mean secara keseluruhan yaitu 6,70 sehingga dapat disimpulkan bahwa aspek tangible Jurusan Sosiologi dalam memberikan layanan pendidikan pada kategori bagus.

Tabel 8. Analisis Penilaian Responden tentang Tangible Jurusan Sosiologi dalam Pelayanan Pendidikan

\begin{tabular}{|c|c|c|c|c|c|c|c|}
\hline No & Pertanyaan & Kurang & Cukup & Baik & Sangat Baik & Total & Mean \\
\hline 1 & $\begin{array}{l}\text { Kantor Jurusan Sosiologi bersh, } \\
\text { dan }\end{array}$ & $2(0,94 \%)$ & $5(2,36 \%)$ & $39(18,40 \%)$ & $166(78,30 \%)$ & $212(100 \%)$ & 7,09 \\
\hline 2 & Kantor Jurusan Sosiologi rapi & $3(1,42 \%)$ & $10(4,72 \%)$ & $46(21,70 \%)$ & $153(72,17 \%)$ & $212(100 \%)$ & 6,97 \\
\hline 3 & Kantor Jurusan Sosiologi nyaman & $17(8,02 \%)$ & $21(9,91 \%)$ & $58(27,36 \%)$ & $116(54,72 \%)$ & $212(100 \%)$ & 6,09 \\
\hline 4 & Ruangan staf jurusan bersih & $9(4,25 \%)$ & $11(5,19 \%)$ & $58(27,36 \%)$ & $13463,21 \%)$ & $212(100 \%)$ & 6,59 \\
\hline 5 & Ruangan staf jurusan rapi & $3(1,42 \%)$ & $7(3,30 \%)$ & $36(16,98 \%)$ & $166(78,30 \%)$ & $212(100 \%)$ & 7,08 \\
\hline 6 & Ruangan staf jurusan nyaman & $4(1,89 \%)$ & $10(4,72 \%)$ & $53(25 \%)$ & $145(68,40 \%)$ & $212(100 \%)$ & 6,81 \\
\hline 7 & $\begin{array}{l}\text { Tersedianya ruang baca dan } \\
\text { sumber pendukung yaitu mini } \\
\text { perpustakaan yang berada di } \\
\text { Jurusan Sosiologi }\end{array}$ & $5(2,36 \%)$ & $9(4,25 \%)$ & $57(26,89 \%)$ & $141(66,51 \%)$ & $212(100 \%)$ & 6,7 \\
\hline 8 & $\begin{array}{l}\text { Tersedianya media (kotak) saran } \\
\text { untuk menampung masukan dan } \\
\text { kritik dari mahasiswa }\end{array}$ & $3(1,42 \%)$ & $8(3,8 \%)$ & $71(33,49 \%)$ & $130(61,32 \%)$ & $212(100 \%)$ & 6,67 \\
\hline 9 & $\begin{array}{l}\text { Media sosial jurusan sosiologi } \\
\text { memberkan informasi mengenai } \\
\text { aktivitas Jurusan }\end{array}$ & $42(19,81 \%)$ & $30(14,15 \%)$ & $59(27,83)$ & $81(38,21 \%)$ & $212(100 \%)$ & 5,14 \\
\hline 10 & $\begin{array}{l}\text { Tersedianya papan pengumuman } \\
\text { yang memuat informasi Jurusan } \\
\text { Sosiologi }\end{array}$ & $3(1,42 \%)$ & $8(3,77 \%)$ & $52(24,53 \%)$ & $149(70,28 \%)$ & $212(100 \%)$ & 6,9 \\
\hline 11 & $\begin{array}{l}\text { Tersedianya panduan penulisan } \\
\text { skripsi bagi mahasiswa }\end{array}$ & $3(1,42 \%)$ & $6(2,83 \%)$ & $37(17,45 \%)$ & $166(78,30 \%)$ & $212(100 \%)$ & 7,1 \\
\hline 12 & $\begin{array}{l}\text { Tersedianya informasi yang } \\
\text { memuat Visi dan Misi Jurusan } \\
\text { Sosiologi }\end{array}$ & $3(1,42 \%)$ & $4(1,89 \%)$ & $22(10,38 \%)$ & $183(86,32 \%)$ & $212(100 \%)$ & 7,32 \\
\hline 13 & $\begin{array}{l}\text { kemudahan dalam mengakses } \\
\text { wifi kampus di Jurusan sosiologi }\end{array}$ & $13(6,13 \%)$ & $16(7,55 \%)$ & $49(23,11 \%)$ & $134(63,21 \%)$ & $212(100 \%)$ & 6,46 \\
\hline 14 & $\begin{array}{l}\text { Tersedianya ruang Ujian skripsi } \\
\text { yang bersih, rapi dan nyaman }\end{array}$ & $5(2,36 \%)$ & $6(2,83 \%)$ & $44(20,75 \%)$ & $157(74,06 \%)$ & $212(100 \%)$ & 6,93 \\
\hline
\end{tabular}




\section{B.2 Analisis Kepuasan Mahasiswa}

Grafik 3. Tanggapan Responden Mengenai Layanan Jurusan dalam Memberikan Informasi Akademik Kepada Mahasiswa

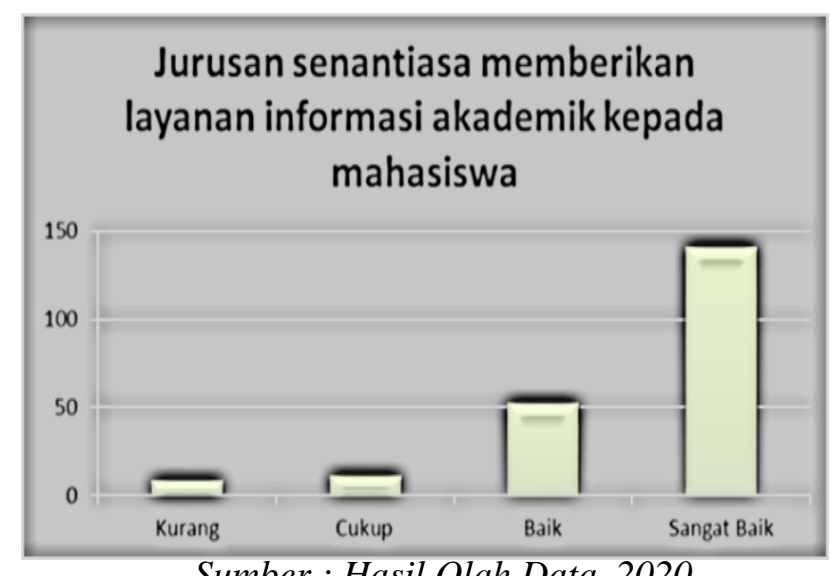

Sumber : Hasil Olah Data, 2020

Berdasarkan grafik 3 dapat kita ketahui bahwa mayoritas responden menilai sangat baik kepada jurusan dalam hal memberikan layanan informasi akademik kepada mahasiswa (141 orang/66,51\%). Contoh layanan informasi akademik yang dimaksud seperti kebijakan universitas dan jurusan terkait proses belajar-mengajar, informasi beasiswa, dan sebagainya.

Grafik 4. Tanggapan Responden Mengenai Pelayanan Administrasi Jurusan

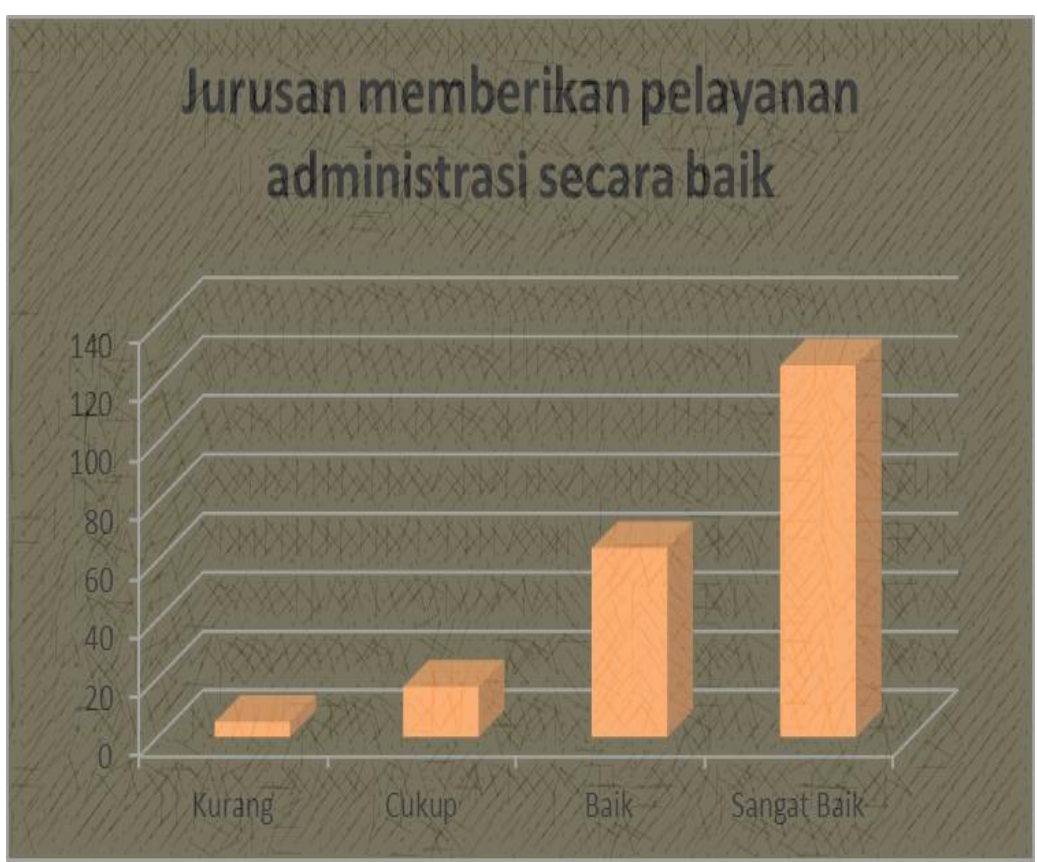

Sumber : Hasil Olah Data, 2020 
Grafik 4 menunjukkan bahwa mayoritas responden menilai sangat baik kepada jurusan dalam hal memberikan pelayanan administrasi secara baik (126 orang/59,43\%). Contoh pelayanan administrasi yang dimaksud disini adalah pelayanan yang dilakukan oleh pengelola jurusan dan staf terkait persoalan akademik dan administrasi mahasiswa, yaitu pembuatan surat cuti, pengisian KRS, pembuatan surat izin pengaktifan kembali, pembuatan SK pembimbing dan penguji skripsi, konsultasi tentang dosen pembimbing dan proses pembimbingan, dan sebagainya.

Grafik 5. Tanggapan Responden Mengenai Penyediaan Ruang Informasi Oleh Jurusan yang Mendukung Civitas Akademika

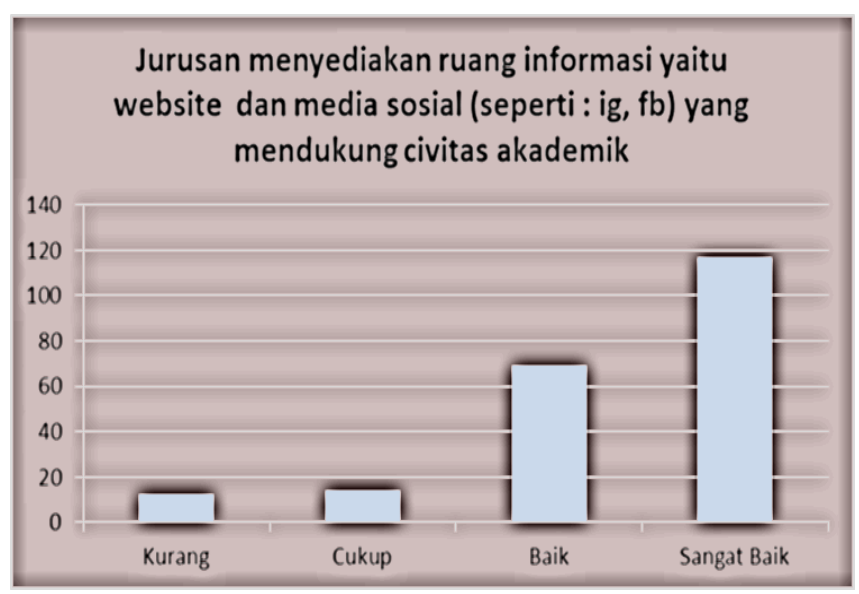

Sumber : Hasil Olah Data, 2020

Grafik 5 menunjukkan mayoritas responden menilai sangat baik kepada jurusan dalam hal menyediakan ruang informasi yaitu website dan media sosial (seperti ig,fb) yang mendukung civitas akademik. Tahun 2020 ini, jurusan Sosiologi telah memiliki website. Untuk media sosial seperti ig, facebook sudah lama dioperasionalkan oleh jurusan Sosiologi. Berkaitan dengan hal ini, jurusan Sosiologi memiliki tim yang mengelola website dan media sosial jurusan. Mereka ini adalah 6 orang mahasiswa yang terpilih melalui seleksi. Tim ini disebut dengan TIM SQUAD jurusan Sosiologi. Mereka bertugas meliput berita seputar jurusan dan sekitarnya kemudian mempublikasikannya melalui media-media yang dimiliki jurusan. 
Grafik 6. Tanggapan Responden Mengenai Dukungan Jurusan secara Akademik kepada Bidang Kemahasiswaan

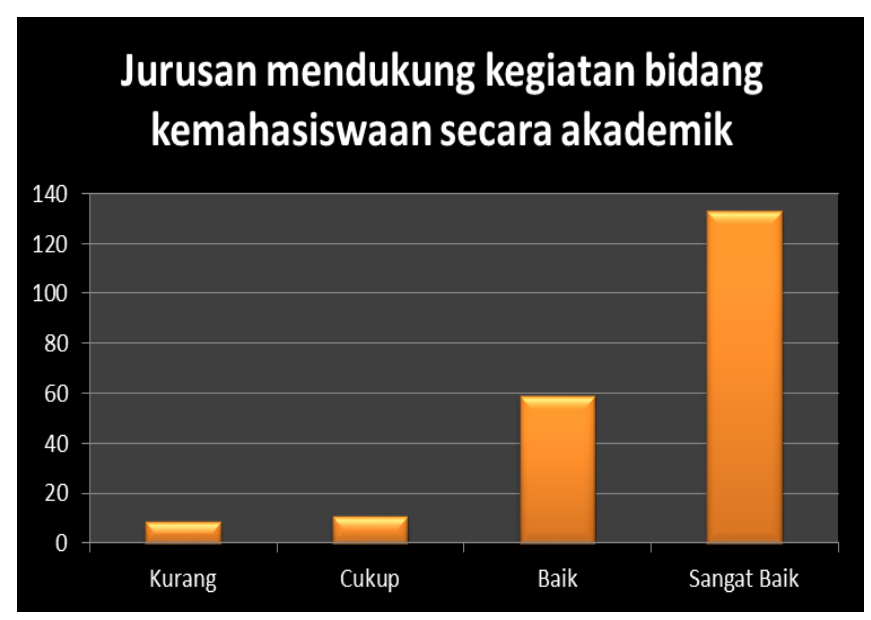

Sumber : Hasil Olah Data, 2020

Grafik 6 menunjukkan mayoritas responden menilai sangat baik kepada jurusan dalam hal mendukung kegiatan bidang akademik kemahasiswaan secara secara akademik. Berkaitan dengan ini jurusan Sosiologi menjalin kerja sama dengan himpunan mahasiswa Sosiologi (HIMA SOS). Bentuk kerja sama jurusan dengan HIMA SOS misalnya bahumembahu dalam melaksanakan kegiatan besar jurusan seperti kegiatan Kuliah Umum, Seminar Nasional, Seminar Daerah, Pelatihan Publik Speaking, Workshop Pembuatan Film dan lain-lainnya, yang mana mahasiswa dilibatkan sebagai panitia. Selain itu jurusan Sosiologi melibatkan mahasiswa dalam kegiatan pengabdian pada masyarakatDesa Mitra- dan penelitian dosen. Lalu jurusan pun memfasilitasi menghadirkan narasumber/pemateri dalam kegiatan HIMA SOS dan memfasilitasi bantuan dana bagi mahasiswa yang ingin berkompetisi pada kegiatan akademik, seperti lomba debat Sosiologi, lomba karya tulis ilmiah dan kegiatan pertemuan mahasiswa jurusan Sosiologi di forum nasional. Namun sayang bantuan dana yang disediakan tersebut belum dimanfaatkan secara maksimal.

Pada grafik 7 dapat diketahui bahwa mahasiswa menilai sangat baik program kegiatan jurusan berupa seminar dan workshop sebagai pendukung kegiatan akademik. Sejak tahun 2016, Jurusan Sosiologi menyelenggarakan kegiatan-kegiatan bermuatan akademis tidak saja untuk mahasiswa Sosiologi UNIB, tapi juga untuk masyarakat. Contoh kegiatan yang sasarannya khusus mahasiswa Sosiologi UNIB adalah kuliah umum, pelatihan public speaking and presentation, workshop pembuatan film untuk 
proses pembelajaran. Contoh kegiatan yang sasarannya mahasiswa Sosiologi UNIB dan masyarakat seperti seminar nasional, seminar daerah, pelatihan untuk guru-guru Sosiologi se-Kota Bengkulu dan lomba karya tulis ilmiah.

Grafik 7. Tanggapan Responden terhadap Jurusan dalam Rangka Penyelenggaraan

Kegiatan Seminar dan Workshop Sebagai Pendukung Akademik

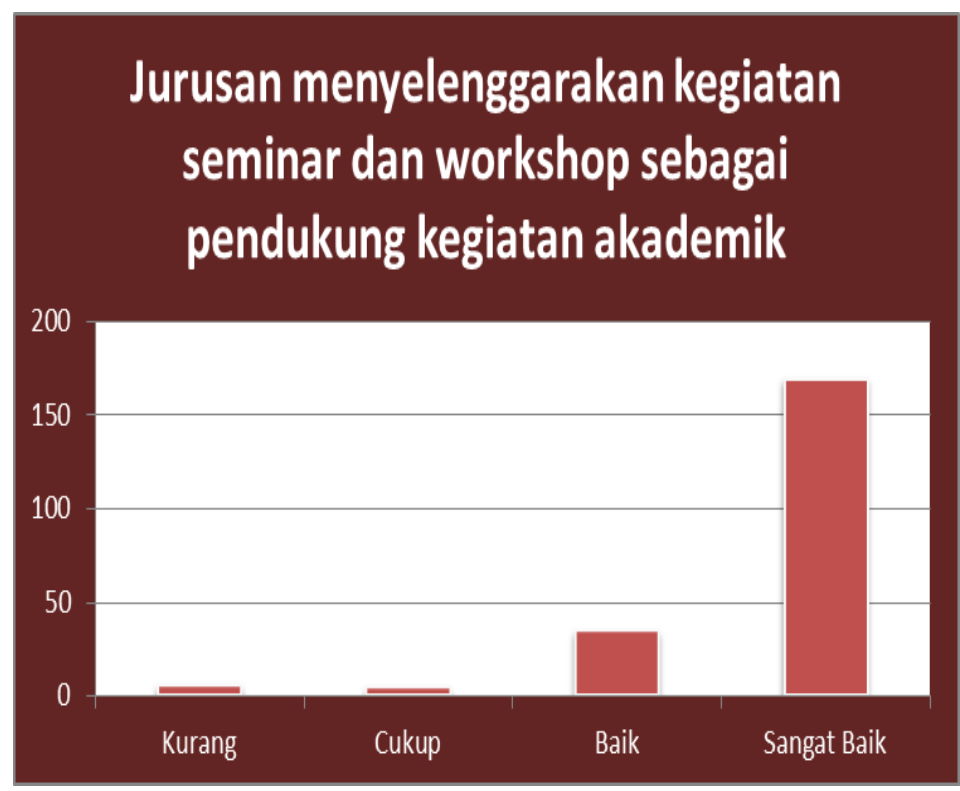

Sumber : Hasil Olah Data, 2020

Grafik 8. Tanggapan Responden terhadap Jurusan dalam Pemberian Informasi Mengenai Peluang Kerja

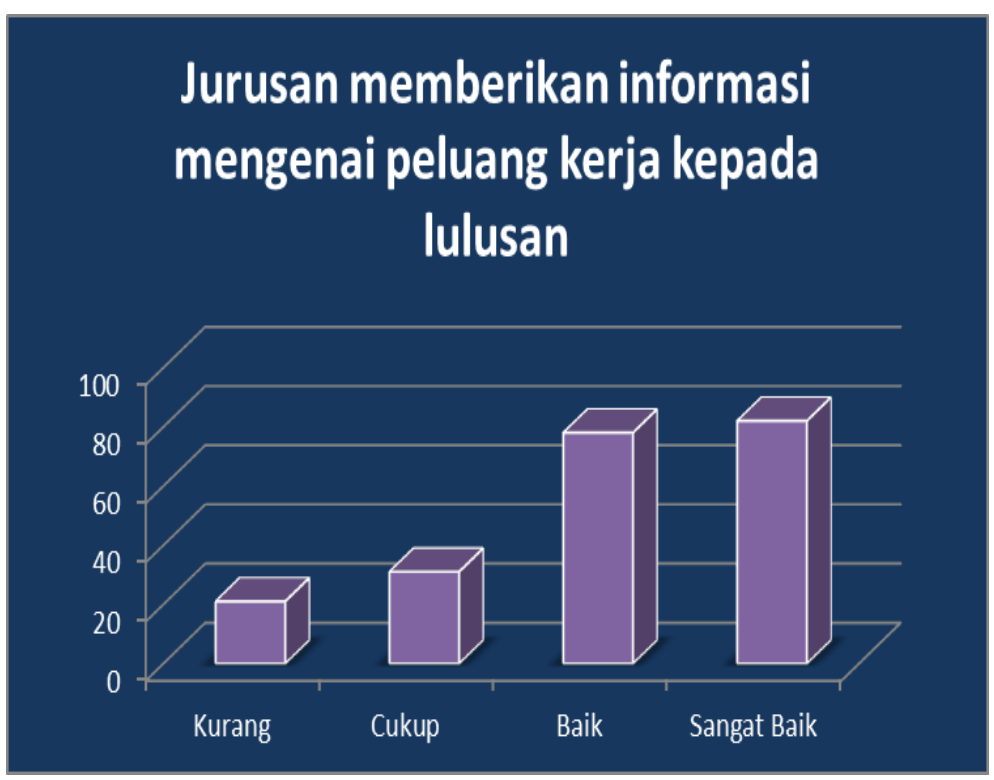

Sumber : Hasil Olah Data, 2020 
Pada grafik 8, mahasiswa menilai sangat baik kepada jurusan Sosiologi dalam hal memberikan informasi mengenai peluang kerja kepada lulusan Sosiologi nantinya. Kegiatan memberikan informasi mengenai peluang kerja kepada mahasiswa Sosiologi ini biasanya dilakukan pada saat pertemuan pertama jurusan dengan mahasiswa baru yaitu pada kegiatan Pengenalan Kehidupan Kampus (PKK) Mahasiswa Baru. Di kesempatan lain pun juga disampaikan tentang peluang kerja bagi lulusan mahasiswa Sosiologi yaitu dalam forum kuliah umum dan terkadang dalam proses belajar-mengajar. Berdasarkan pemaparan data-data tersebut di atas maka dapat disimpulkan bahwa mahasiswa merasa puas dengan layanan pendidikan yang diberikan oleh Jurusan Sosiologi. Ini didasarkan pada penilaian responden yang mayoritas sangat baik terhadap semua pernyataan yang berkaitan dengan kepuasan pengguna terhadap layanan yang diberikan institusi.

\section{KESIMPULAN}

Berdasarkan hasil hitung nilai rata-rata variabel, maka seluruh aspek terkait layanan pendidikan Jurusan Sosiologi kepada pengguna (mahasiswa) pada kategori bagus. Aspek -aspek tersebut adalah : Keandalan, meliputi : Kemampuan dosen sebagai pengajar, nilai mean 6,56 = bagus), Kemampuan dosen sebagai pembimbing akademik, nilai mean 6,27 = bagus), Kemampuan dosen sebagai pembimbing penyusunan skripsi, nilai mean $6,26=$ bagus) Keandalan staf, nilai mean 6,62 = bagus Keandalan pengelola jurusan, nilai mean $=6,96$ Daya tanggap, nilai mean $6,80=$ bagus. Kepastian, nilai mean $6,65=$ bagus Empati, nilai mean 7,12 = bagus. Tangible, nilai mean $6,70=$ bagus . Berdasarkan hasil hitung nilai rata-rata variabel pada poin 1 yang keseluruhannya pada kategori penilaian bagus serta penilaian responden yang mayoritas sangat baik terhadap semua pernyataan yang berkaitan dengan kepuasan pengguna terhadap layanan yang diberikan institusi, maka dapat disimpulkan bahwa mahasiswa merasa puas dengan layanan pendidikan yang diberikan oleh Jurusan Sosiologi.

\section{DAFTAR PUSTAKA}

Idrus, Muhammad. 2009. Metode Penelitian Ilmu Sosial : Pendekatan Kualitatif dan Kuantitatif. Yogyakarta : PT Gelora Aksara Pratama.

Ilyas . 2014. Tingkat Kepuasan Mahasiswa Terhadap Layanan Akademik Dosen Pendidikan Agama Islam (Penelitian Pada Mahasiswa Semester II Fakultas Ilmu 
$\begin{array}{lll}\text { Pendidikan Universitas Nemarang). } & \text { Neri }\end{array}$ https://journal.unnes.ac.id/nju/index.php/JPP/article/view/5700

Islamy, M. A., Wahyudin, D., \& Margana, H. H. (2016). Analisis Tingkat Kepuasan Pemustaka Tentang Kualitas Layanan Perpustakaan Dengan Menggunakan Metode Libqual+ (Studi Deskriptif Di Perpustakaan Pusat Institut Teknologi Bandung). Edulib, 1(1), 1-11. http://eprints.rclis.org/2/antologijurnal_Mabdillah_1206396_edulb.pdf

Mardikawati, woro dan Naili Farida. 2013. "Pengaruh Nilai Pelanggan dan Kualitas Layanan Terhadap Loyalitas Pelanggan, Melalui Kepuasan Pelanggan Pada Pelanggan Bus Efisiensi Studi Po Efisiensi Jurusan Yogyakarta-Cilacap)”, Jurnal Administrasi Bisnis, (Vol. 2, No. 1, Maret/2013)

Nafidah, N. 2015. Pengaruh kinerja pustakawan terhadap kepuasan pemustaka pada perpustakaan universitas indonesia. UIN Syarif Hidayatullah Jakarta.

Parasuraman, A., Zeithaml V. A., dan Berry L. L. 1994. "Servqual: Alternative Scales for Measuring Service Quality?AComparative Assessment Based on Psychometric and Diagnostic Criteria.” Journal of Retailing, Vol. 70, No. 1, hal. 193-199.

Rahayuningsih, F. 2015. Mengukur Kepuasan Pemustaka: Menggunakan Metode Libqual (1st ed.). Yogyakarta: Graha Ilmu

Silalahi, Ulber . 2010. Metode Penelitian Sosial. Bandung : PT Refika Aditama Sopiatin, Popi. 2010. Manajemen Belajar Berbasis Kepuasan Siswa. Bogor: Ghalia

Sudirman, Rio. 2010. Analisis Pengaruh Kualitas Pelayanan terhadap Kepuasan Mahasiswa dan Citra Perguruan Tinggi. Diperoleh dari http://untagbanyuwangi.ac.id/attachments/article/347/ANALISIS\%20\%20

PENGARUH\%20\%20KUALITAS\%20 PELAYANAN\%20TERHADAP\%20 KEPUASAN\%20.pdf.

Sugiyono. 2018. Metode Penelitian Kuantitatif, Kualitatif dan RD. Bandung : Alfabeta

Sukanti. 2009. Analisis Kepuasan Mahasiswa Program Studi Pendidikan Akuntansi Fise Uny. Jurnal Pendidikan Akuntansi Indonesia Vol. VIII. No. 1 - Tahun 2009 Hal $23-34$ 